\title{
Pemanfaatan Batang Napier Untuk Menghitung Operasi Perkalian Dan Pembagian
}

\author{
Malalina $^{1}$, Rika Firma Yenni ${ }^{2}$ \\ ${ }^{1,2}$ Program Studi Pendidikan Matematika, FKIP, Universitas Tamansiswa Palembang \\ e-mail: ${ }^{* 1}$ Malalina@unitaspalembang.ac.id, ${ }^{2}$ rika_firma@unitaspalembang.ac.id
}

Informasi Artikel

Diterima Redaksi: 29 April 2019

Revisi Akhir: -

Diterbitkan Online: 6 Mei 2019

Kata Kunci

Batang Napier, Perkalian, Pembagian

Korespondensi

No. HP: 081279882224

\section{Abstract}

Salah satu faktor keberhasilan dalam mengajarkan matematika di sekolah dasar adalah penggunaan media pembelajaran yang di sesuai dengan materi. Salah satu media yang dapat digunakan untuk pembelajaran matematika untuk operasi perkalian dan pembagian adalah batang napier. Batang napier dapat digunakan oleh siswa dalam membantu perhitungan operasi perkalian dan pembagian. Kegiatan pengabdian kepada masyarakat ini dilaksanakan selama 3 kali pertemuan tatap muka yang dilaksanakan di Kelas IV Madrasah Al-Hilaliyah. Metode yang digunakan dalam kegiatan pengabdian ini berupa Ceramah, Praktek langsung dan Diskusi. Kesimpulan yang didapatkan setelah melaksanakan kegiatan pengabdian masyarakat adalah sebagai berikut berdasarkan hasil evaluasi seluruh siswa dapat menggunakan batang napier. Hal ini terlihat dari semua siswa menjawab soal operasi perkalian dan pembagian batang napier dengan benar; Seluruh siswa sangat antusias dalam mengikuti kegiatan ini. Hal ini ditunjukkan dengan tingkat kehadiran seluruh peserta mulai dari awal kegiatan sampai akhir kegiatan mencapai 100\%; Siswa sangat termotivasi mengerjakan soal perkalian dan pembagian, hal ini terlihat dari hasil evaluasi yang dikerjakan oleh siswa. 


\section{PENDAHULUAN}

Peranan yang sangat penting untuk memperkenalkan ilmu pengetahuan dasar adalah di tingkat sekolah dasar. Pembelajaran di sekolah dasar adalah proses siswa untuk mengetahui kemampuan dasar sejak usia dini. Menurut Piaget siswa sekolah dasar yang berusia 6 sampai dengan 13 tahun masih berada dalam fase operasional kongkret. Fase operasional kongkret adalah suatu kemampuan dalam proses berfikir untuk mengoperasikan kaidahkaidah logika, meskipun masih terikat dengan objek yang bersifat kongkret (Heruman, 2008:1). Mulai dari taman kanak-kanak khususnya pembelajaran matematika sudah diperkenalkan walaupun secara informal. Sehingga pada saat siswa sudah memasuki tingkat sekolah dasar siswa sudah biasa untuk melakukan proses perhitungan dan proses penalaran yang dibutuhkan untuk meyelesaikan berbagai masalah yang terkait dengan matematika dalam kehidupan sehari-hari. Kurikulum matematika pada sekolah dasar membangun kemampuan dasar yang kokoh tentang pemahaman konsep, ideide, gagasan, aturan-aturan, logika dalam matematika, menggunakan penalaran dan pembuktian untuk memecahkan masalah kehidupan (Depdiknas, 2007).

Zulkardi (2005), menyatakan permasalahan inti dalam pendidikan matematika di Indonesia yaitu rendahnya mutu pendidikan yang ditunjukkan oleh rendahnya prestasi siswa baik pada skala nasional maupun internasional. Rendahnya prestasi siswa tersebut terkait komponen-komponen pembelajaran matematika di sekolah, diantaranya materi, media dan metode.
Sejalan dengan hal itu, Mujiono (1994: 31) menyatakan proses belajar mengajar ada empat komponen penting yang berpengaruh bagi keberhasilan belajar siswa, yakni bahan belajar, suasana belajar, media dan sumber belajar,serta guru sebagai subyek pembelajaran. Proses pembelajaran sangan ditentukan dari empat komponen tersebut. Sehingga melemahnya satu atau lebih komponen dapat menghambat tercapainya tujuan belajar yang maksimal.

Salah satu faktor keberhasilan dalam mengajarkan matematika di sekolah dasar adalah penggunaan media pembelajaran yang di sesuai dengan materi. Media pembelajaran mempunyai peranan yang sangat penting dalam proses pembelajaran. Sehingga penggunaan media pembelajaran yang tepat akan sangat membantu siswa dalam memahami materi. Arsyad (2011:15) fungsi utama media pembelajaran adalah alat bantu mengajar yang mempengaruhi iklim, kondisi, dan lingkungan belajar yang ditata dan diciptakan oleh guru.

Salah satu media yang dapat digunakan untuk pembelajaran matematika untuk operasi perkalian dan pembagian adalah batang napier. Batang napier dapat digunakan oleh siswa dalam membantu perhitungan operasi perkalian dan pembagian (Sumardyono dkk, 2011). Batang napier adalah suatu media pembelajaran yang digunakan untuk membantu perhitungan operasi perkalian dan pembabagian menjadi penjumlahan.

Batang napier di temukan oleh seorang matematikawan abad ke 16 yang bernama John Napier pada tahun 1617 atau disebut dengan tulang napier. Untuk menghormati jasa beliau dinamakanlah batang napier. Batang napier terdiri atas beberapa batang atau keping yang dapat dipisah-pisahkan, yaitu keping pertama merupakan indeks yang bertuliskan angka 0 sampai 
dengan 9 sebagai bilangan pengali, keping kedua merupakan kelompok hasil kali dengan bilangan 0 , keping ketiga merupakan kelompok hasil kali dengan bilangan 1, keping keempat merupakan kelompok hasil kali dengan bilangan 2, dan seterusnya hingga keping kelompok hasil kali dengan bilangan 9. Jadi seluruhnya ada 11 keping. (Sumardyono dkk, 2011). Berikut ini adalah batang napier yang digunakan dalam kegiatan pengabdian :

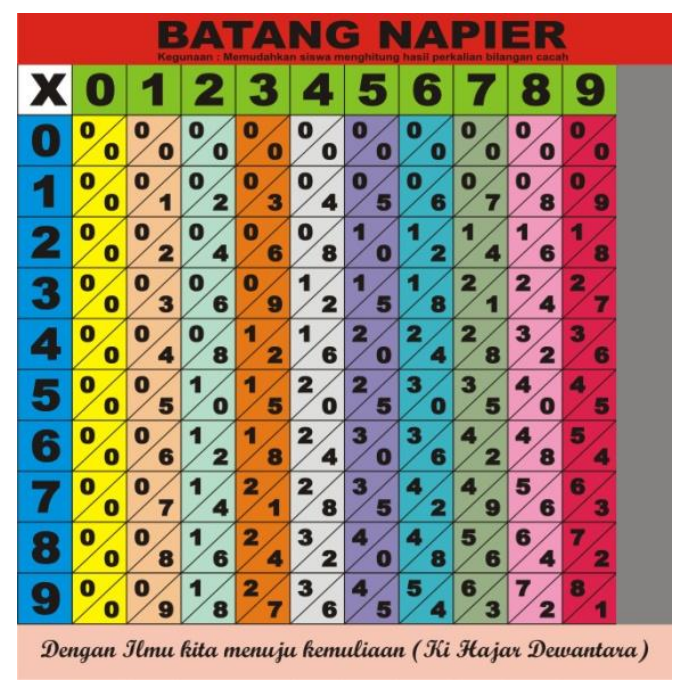

Gambar 1 Media Pembelajaran Batang Napier

Batang napier mirip dengan tabel perkalian yang dituliskan dengan cara berbeda. Perhatikan gambar 1 diatas, Misalkan untuk $4 \times 5$, pada tabel perkalian dapat dibaca Pada batang napier, hasil $4 \times 5$ yang dituliskan dengan

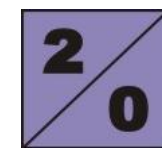

Gambar 2 Indek Batang Napier

Batang napier digunakan untuk membantu perhitungan perkalian dan pembagian bilangan satuan kali puluhan, satuan kali ratusan, dan seterusnya.

Contoh $4 \times 524=\ldots$

1. Pasangkan keping kelompok hasil

perkalian 5, keping hasil perkalian 2 dan kepingan hasil kali 4 dengan keping indeks seperti gambar berikut.

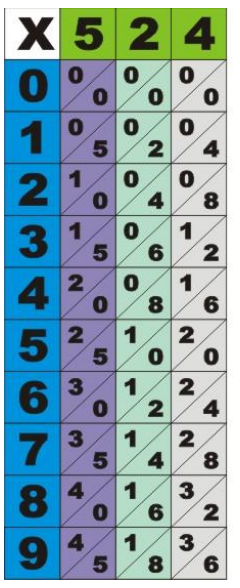

Gambar 3. Perkalian Batang Napier

2. Perhatikan Perkalian 4 dan 524 seperti gambar dibawah ini dan jumlahkan secara diagonal seperti gambar berikut ini :

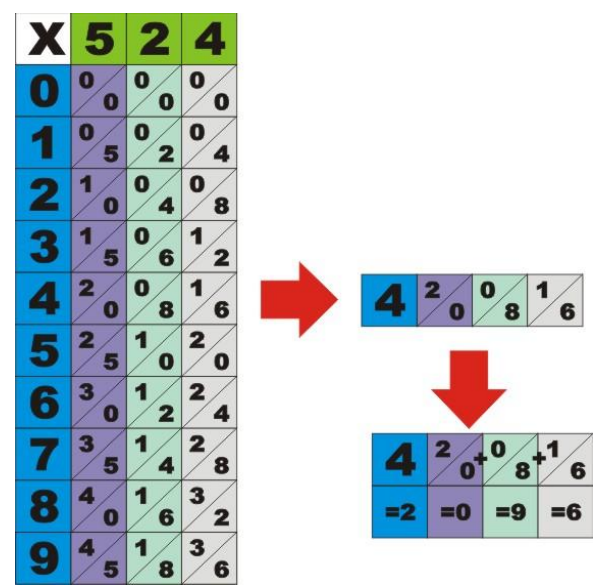

Gambar 4. Perhitungan Perkalian Batang Napier

Hitunglah 968: $4=\ldots$

Maka yang kita lakukan adalah memasangkan batang indeks dengan batang 4 , kemudain perhatikan gambar dibawah ini 


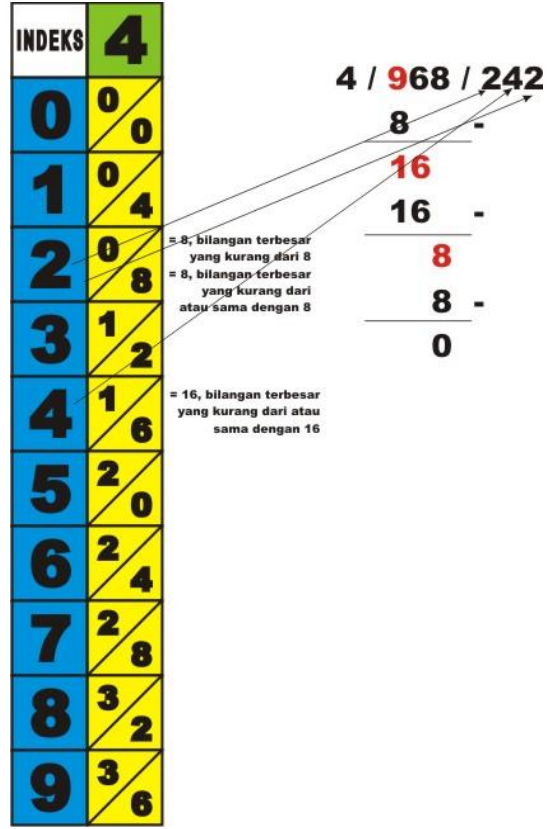

Gambar 5. Perhitungan Pembagian pada Batang Napier

Penggunaan batang napier dalam pembelajaran sangat sederhana dan mudah serta cepat untuk menghitung operasi perkalian dan pembagian dengan bilangan-bilangan dari yang terkecil sampai besar. Penggunaan batang napir membuat siswa merasa senang dan termotivasi untuk belajar perkalian dan pembagian. Sebagian siswa mengalami kesulitan dalam menghitung perkalian bilangan besar, sehingga dengan batang napier menghitung perkalian menjadi lebih mudah dan cepat dibandingkan dengan cara bersusun. Melalui kegiatan pengabdian masyarakat penggunaan batang napier untuk menghitung operasi perkalian dan pembagian diharapkan kemampuan siswa dalam menghitung semakian meningkat. Selain itu, penggunaan batang napier ini membuat pembelajaran lebih menyenangkan dan menarik. Sehingga diharapkan dapat membuat pemahaman matematika dapat meningkat.

\section{METODE}

\subsection{Waktu dan Tempat Pelaksanaan}

Kegiatan pengabdian kepada masyarakat ini dilaksanakan selama 3 kali pertemuan tatap muka. Satu kali tatap muka dibutuhkan waktu selama 3 Jam. Waktu pelaksanaan adalah sebagai berikut :

Tabel 1 Waktu Pelaksanaan

\begin{tabular}{|c|c|c|c|}
\hline $\begin{array}{l}\mathrm{N} \\
\mathrm{O}\end{array}$ & $\begin{array}{c}\text { Pertemua } \\
\mathrm{n}\end{array}$ & Materi & Pelaksana \\
\hline 1 & $\begin{array}{l}\text { Pertemua } \\
\text { n } \\
\text { Pertama / } \\
8 \text { Maret } \\
2019\end{array}$ & $\begin{array}{c}\text { Operasi } \\
\text { Perkalian }\end{array}$ & $\begin{array}{c}\text { Tim } \\
\text { Pengabdia } \\
\mathrm{n}\end{array}$ \\
\hline 2 & $\begin{array}{c}\text { Pertemua } \\
\text { n Kedua / } \\
13 \text { Maret } \\
2019\end{array}$ & $\begin{array}{c}\text { Operasi } \\
\text { Pembagia } \\
n\end{array}$ & $\begin{array}{c}\text { Tim } \\
\text { Pengabdia } \\
\mathrm{n}\end{array}$ \\
\hline 3 & $\begin{array}{c}\text { Pertemua } \\
\text { n Ketiga } \\
\text { / } 16 \\
\text { Maret } \\
2019\end{array}$ & Evaluasi & $\begin{array}{c}\text { Tim } \\
\text { Pengabida } \\
\mathrm{n}\end{array}$ \\
\hline
\end{tabular}

Berdasarkan Tabel 1 Pada Pertemuan pertama yaitu penjelasan materi operasi perkalian dengan batang napier begitu juga dengan pertemuan kedua tetapi menggunakan materi operasi perkalian. Pertemuan ketiga merupakan pertemuan akhir kegiatan yang dilakukan adalah evaluasi yaitu siswa diberikan beberapa soal untuk mengetahui tingkat pemahaman oeprasi perkalian dan pembagian menggunakan batang napier. Kegiatan Pengabdian Masyarakat ini dilaksanakan di Kelas IV Madrasah Al-Hilaliyah Palembang. 


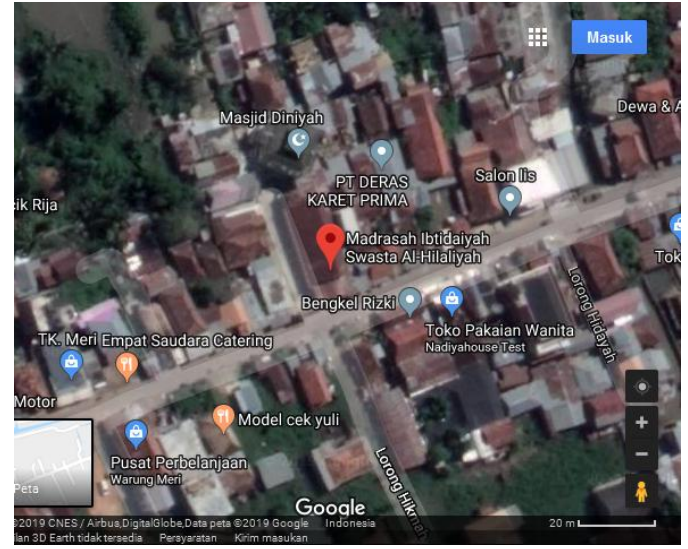

Gambar 6. Tempat Pelaksanaan

\subsection{Metode Pelaksanaan}

Metode yang digunakan dalam kegiatan pengabdian ini berupa :

a. Ceramah

Metode ceramah digunakan untuk memotivasi siswa dalam mempelajari materi matematika. Selain itu dijelaskan juga bagaimana penggunaan batang napier dalam menghitung perkalian dan pembagian. Selama kegiatan berlangsung sisa juga mendapatkan modul penggunaan batang napier untuk menghitung perkalian dan pembagian.

b. Praktek langsung

Setalh dilakukan penjelasan dalam metode ceramah, dilakukan praktek langsung kepada siswa, dengan pemberian batang napie kepada setia siswa. Sehingga siswa dapat praktek langsung menghitung soal perkalian dengan menggunakan batang napier.

c. Diskusi

Metode diskusi dugunakan untuk menyelesaikan kesulitan siswa jika dalam penggunaan batang napier siswa mengalami kesulitan.

\section{HASIL DAN PEMBAHASAN}

Kegiatan pengabdian masyarakat ini di bagi dalam 3 kali pertemuan, pertemuan pertama menjelaskan operasi perkalian, pertemuan kedua menjelaskan operasi pembagian dan pertemuan terakhir merupakan evaluasi. Berikut penjelasan pada tiap pertemuan.

Pertemuan pertama dilaksanakan pada hari Jumat tanggal 8 Maret 2019 pukul 07.30-10.00 dimulai dengan pembukaan oleh Kepala Sekolah. Penyampaian media pembelajaran batang napier, sejarah batang napier, praktek langsung penggunaan batang napier pada operasi perkalian.

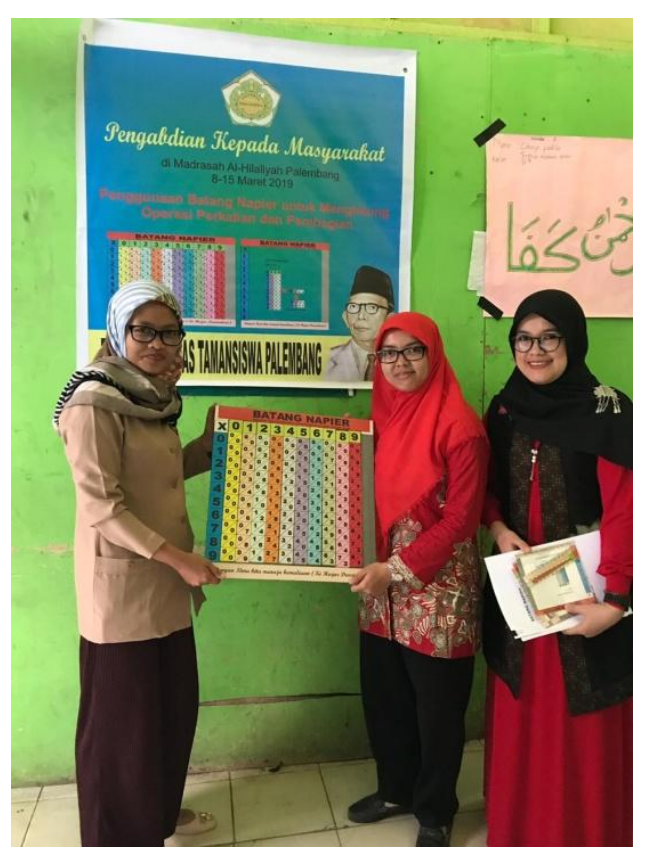

Gambar 7 Penyerahan Media kepada Pihak Sekolah

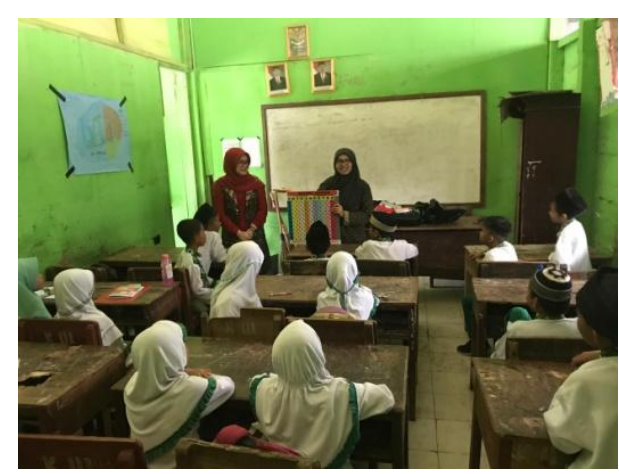

Gambar 8. Penyampaian Materi

Pertemuan Kedua dilaksanakan pada hari Rabu tanggal 13 Maret pukul 07.30 - 10.200. Pada pertemuan kedua diawali dengan praktek langsung 
penggunaan batang napier pada operasi pembagian Praktek secara langsung ini bertujuan memberikan pengalaman dan pembelajaran menggunakan media pembelajaran batang napier untuk menghitung operasi pembagian.

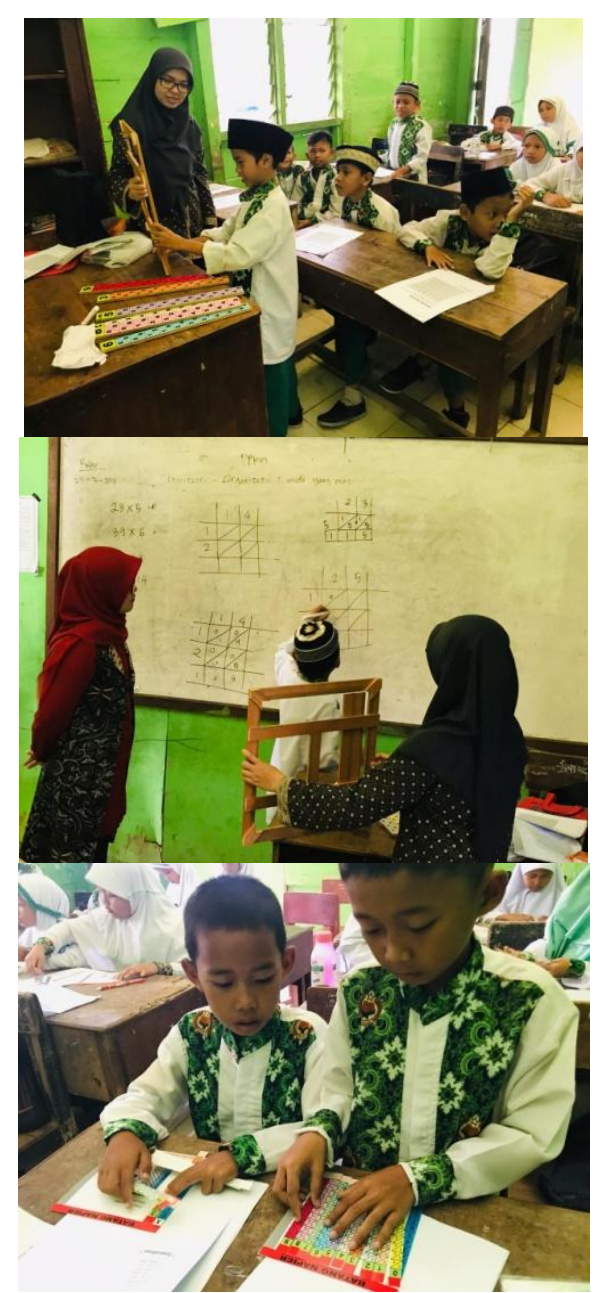

Gambar 9. Praktek Langsung

Pada pertemuan ketiga tanggal 15 Maret 2019 pukul 08.00 - 10.00 dilakukan evaluasi yaitu mengerjakan soal-soal perkalian dan pembagian menggunakan batang napier.

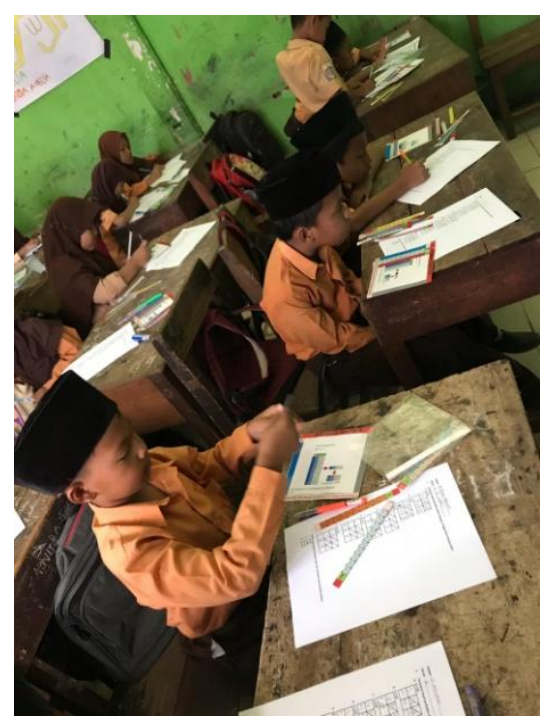

Gambar 10 Evaluasi

Setelah dilaksanakan kegiatan pengabdian selama 3 kali pertemuan di dapatkan bahwa siswa dapat menggunakan dengan baik batang napier dalam menghitung operasi perkalian dan pembagian. Selain itu siswa sangat antusia dalam mengikuti kegiatan ini. Hal ini terlihat dari selama 3 kali pertemuan tingkat kehadiran peserta yaitu $100 \%$. Siswa juga sangat termotivasi untuk mempelajari soal-soal perkalian batag napier dengan jenis soal yang berbeda.

\section{KESIMPULAN}

Kesimpulan yang didapatkan setelah melaksanakan kegiatan pengabdian masyarakat adalah sebagai berikut :

1. Berdasarkan hasil evaluasi seluruh siswa dapat menggunakan batang napier. Hal ini terlihat dari semua siswa menjawab soal operasi perkalian dan pembagian batang napier dengan benar.

2. Seluruh siswa sangat antusias dalam mengikuti kegiatan ini. Hal ini ditunjukkan dengan tingkat kehadiran seluruh peserta mulai dari awal kegiatan sampai akhir kegiatan mencapai $100 \%$.

3. Siswa sangat termotivasi mengerjakan soal perkalian dan pembagian, hal ini terlihat dari hasil evaluasi yang dikerjakan oleh 
siswa.

\section{SARAN}

Saran untuk kegiatan pengabdian ini adalah Tim Peneliti harus bisa menjaga ketertiban kegiatanpengabdian masyarakat dikarenakan siswa sangat termotivasi dan aktif mengikuti kegiatan penggunaan media pembelajaran batang napier sehingga membuat kegaduhan dalam pelaksanaan kegiatan. Selain itu sekolah berharap dapat menggunakan media pembelajaran lain untuk materi yang lain. Sehingga siswa mengetahui setiap materi matematika terdapat media pembelajarannya.

\section{DAFTAR PUSTAKA}

[1] Arsyad, Azhar. (2011). Media Pembelajaran. Jakarta: PT Raja Grafindo Persada.

[2] Depdiknas, (2007). Kajian Kebijakan Kurikulum Mata
Pelajaran Matematika. Jakarta:

Badan Penelitian dan Pengembangan Pust Kurikulum.

[3] Heruman. (2008). Model Pembelajaran Matematika. Bandung: PT. Remaja Rosdakarya.

[4] Mujiono. (1994). Belajar dan Pembelajaran. Jakarta: Dirjen Dikti Mendikbud.

[5] Sumardiono, dkk. (2011). Buku Petunjuk Penggunaan Alat Peraga Matematika. Yogyakarta: PPPPTK Matematika

[6] Zulkardi. (2005). Pendidikan Matematika di Indonesia: beberapa Permasalahan dan Upaya Penyelesaiannya. Pidato disampaikan dalam pengukuhan sebagai guru besar tetap pada FKIP UNSRI.

Palembang. 